\title{
DEVELOPMENT VECTOR OF INFORMATISATION OF SOCIETY
}

\author{
Pavlo Pokataiev', Oleg Matviichuk ${ }^{2}$ \\ Classic Private University, Ukraine
}

\begin{abstract}
The purpose of the paper is to cover the main moments of the state program of informatisation of society and on the basis of the sources used to propose a strategic vision of the further development of the information society in the context of its financing. Methodology. The survey is based on the analysis of the development of information society in Ukraine taking into account features of state policy in the field of informatisation. Laws and regulations that influence the national program of informatisation are outlined. The scientific material, which describes the processes of financing and implementation of the informatisation program, of domestic scientists is indicated. The direction of financing of the state program of informatisation of society in the context of integration into world processes is highlighted. The formation of conclusions and schemes of the vector of development of the information society is based on the research of scientific works and on the basis of our considerations in the context of the use of the intellectual potential of the citizens of the country. Results. The positive directions of foreign investments for funding the state program of informatisation of society, such as competition, innovations, accumulation of capital are outlined. On the example of one of the regions of Ukraine, the main problems are identified, which prevent to more quickly implement the National Program of Informatisation. The way of ensuring national competitiveness and investment attractiveness is proposed, as a result of solving certain problem issues. The algorithm of actions in the form of a vector for the development of the information society, for the improvement of the sustainable development of the information society, is formed. Practical implications. Proposals for developing the information society can be implemented in the state policy of informatisation of state authorities and the country as a whole. The main scientific achievements of this article can be used in the national program of informatisation, which determines the short, medium, and longterm development of the information society in the context of the transformation of social, economic, ecological, scientific and technical, defence, and cultural activities in society at the national level. It is also possible to propose the main content of this scientific material to be used in the future addition of the Concept of the National Program of Informatisation, regional, sectoral programs of informatisation in the context of the management of the implementation of information technologies and programs and projects aimed at improving the infrastructure of the territorial community. Value/originality. Positive and negative tendencies of informatisation of society against the background of the active introduction of the state program of informatisation of society are presented; a scheme is proposed that represents the vector of the development of the information society. The main components of the interaction and growth of the information society are as follows: the negative factors, on the basis of which there is formed the further policy of public administration, tools that can be used in solving current and possible future problem issues, directions of infrastructure development for the implementation of opportunities of the information society, the division of responsibilities between the authorities depending on their resource capacity and maximum capacity to meet the needs of citizens.
\end{abstract}

Key words: investments, financing, public administration.

JEL Classification: E22, F65, H83

\section{Introduction}

At the moment, the formation of the information society and the effective use of information and communication technologies have become a permanent part of the further evolution of society. The programs of the informatisation of society are the main priority of increasing social standards in the countries of the world. However, despite the great potential of information

\footnotetext{
Corresponding author:

${ }^{1}$ Department of Public Administration and Land Use, Classical Private University.

E-mail: victor30077788@gmail.com

${ }^{2}$ Department of Public Administration and Land Use, Classic Private University.

E-mail: Pokataeva.Olga1978@gmail.com
} 
technology, their implementation, unfortunately, is in the plane of uncertainty over the lack of all available instruments provided by the regulatory framework of countries in the transformation period. Although the implementation of information and communication technology is increasing, relative to global trends, the state of the information society in developing countries is in its early stages.

Attracting investments in relation to the program of informatisation was formed on the basis of scientific researches by such scientists as: L.M. Borshch, A.P. Haidutskyi, B.V. Hubskyi, L.L. Antoniuk, A.F. Boiko, V.M. Hrynova, and others. Based on the research of M.F. Tarasenko, N. Wiener, O.M. Riakin, B.V. Biriukov, the essence of information for the society was specified, however, further strategic vision against the background of the introduction of the state program of informatisation and its financing require further research.

The purpose of the paper is to cover the main moments of the state program of informatisation of society and on the basis of the sources used to propose a strategic vision of the further development of the information society in the context of its financing.

\section{National program of informatisation}

The introduction of a national program of informatisation defines a strategy for the development of society, which will affect the social, economic, ecological scientific and technical, defence, national-cultural, and other activities in society at the national level. The national program of informatisation should include the following regulatory documents - the Concept of the National Program of Informatisation; a set of state programs on informatisation; branch programs and informatisation projects; regional programs and projects of informatisation; programs and projects of informatisation of local self-government bodies.

To accelerate the financing of the national program of informatisation of society, it is necessary to identify the main vectors in which the state authorities will create a favourable environment for the growth of financial revenues in projects that will implement the national program of informatisation of society. When financing the informatisation, an attention should be paid to measures aimed at implementing a full range of reliable, timely analysis of all types of human activities that require a general and narrow informatisation of processes. Thus, informatisation and its financial support can be realized only if the intellectual potential of society is actively used and information technology is actively implemented in scientific and industrial activities (Kozak, 2017).

An important role in the national program of informatisation is played by approaches to financing long-term priorities of socio-economic, scientifictechnical, national-cultural development of the country and active involvement in the International Information Space both of Ukraine and most countries of the world. The program of national informatisation itself is a complex system with a project of informatisation of the specialization of the state policy and priority directions of the development of information infrastructure (Zakon Ukrainy, 2016).

Thus, since 1999, the implementation of programs "eEurope", "eEurope 2002", and "eEurope 2005" has started in the countries of the European Union. According to it, the introduction of e-services was envisaged, such as: e-learning; eHealth; e-government. It was planned to create a dynamic (competitive) environment for e-business and secure information infrastructure (Hurkovskyi, 2010).

The Government of the Republic of Italy, in developing the main provisions of information policy, among the main priorities, identified the transformation of government bodies based on ICT, the essence of which was the creation of free online access for citizens and entrepreneurs, the implementation of the computerization program and e-learning for civil servants, the transparency of the state document circulation using the Internet, providing quality information products and services. The fulfilment of the set goals is controlled by the National Centre for Informatics under the State Administration (Centro Nazionale per l'Informatica nella Pubblica Amministrazione, CNIPA) (Riabokon, 2016).

The implementation of state policy in the field of informatisation of society should have a vector of rational use of industrial and scientific and technical potential of material and technical and financial resources for the creation of the modern informational infrastructure for solving issues of economies of the countries of Europe and the world. The use of public funds in the context of the development of the information society, namely, the financial component of processes of implementation of information technologies, should be based on the following: the creation of a national information and telecommunication system; development of the system of national information resources; informatisation of strategic directions of development of the state economy, its security and defence, social sphere (Zakon Ukrainy, 2013).

\section{Financing and implementation of the state program of informatisation of society}

In order to provide funding for the state program of informatisation of society, the national economy should be integrated into world processes, based on internal and external preconditions of the information society's requests. Therefore, the financial component of the information society should balance between the investor's point of view, which may affect the growth of financial resources, the direction of information and 
society, and respond to the economic feasibility of the use of a particular information project and its social component. The attraction of foreign investments to finance state programs is, firstly, the step of creating a project on an international scale and attracting international experience.

Also, it should be noted that foreign investment can be the source of new technologies, management skills, and marketing systems in the field of information society. The attraction of foreign investments to finance the state program of informatisation of society can stimulate competition, innovations, accumulation of capital for the further development of information technologies in all aspects of public administration and state development. The most positive aspects of attracting foreign investment will be the following: 1) modernization of the infrastructure - the active use of international models of production technology and labour organization; 2) increase of production volumes with the help of new information technologies that can optimize approaches to expenses of resources in production; 3) balance of payments; 4) increasing competitiveness. Another important feature of foreign investment is the investment of finance already in the existing infrastructure, which significantly solves the transformational processes of informatisation of society (Zakon Ukrainy, 2013).

The main problems of the development and implementation of the state program of informatisation of society and its financing are:

1) the development of society - the presence of a digital imbalance in access of citizens to the Internet. Unfortunately, the level of computer literacy of the population is slowly growing, as well as signs of low level of implementation and use of information and communication technologies in the social spheres of society;

2) e-government - the presence of problematic issues concerning the development of information society within the framework of communication with state authorities, namely, inter-compatibility (interoperability) of various information systems created at different times, according to different principles, on different technological platforms;

3) development of public administration - low level of cooperation between state authorities and local self-government bodies providing socio-economic and socio-political relations within the framework of informatisation of society (Honcharenko, 2017).

Also, one of the components of the influence on the development of financing the state program of informatisation of society is a number of international assistance programs for the development of small and medium-sized enterprises, which, in turn, affects the active involvement of society in transformational processes through information technologies (Table 1).

On the example of Ukraine, let us consider the introduction of the program of the informatisation of the society. When reviewing the approved electronic information program "Electronic Lviv Region" for 2018-2020, one should note the state and problems of informatisation of the region in the context of financial support of the national program of informatisation of society in Ukraine. During 2014-2016, Ukraine made significant progress - from the 77 th to 32 nd place, in particular, this progress was represented and actively used in the areas of electronic consultations and electronic decisions. A striking example of electronic solutions in Ukraine that influences the provision of the information society program is the development and implementation of the Prozzoro online platform for public procurement, the adoption of laws and regulations in the field of open data, the creation of a State Portal of Open Data, the introduction of e-declaration for public officials' income and property.

On the example of the Lviv region, one can identify the main problems that hinder to introduce more quickly the National Program of Informatisation of Society, namely:

- the absence of a single regional information and telecommunication infrastructure of state authorities; - a large number of outdated computer equipment at various levels of state authorities, which does not allow operating in accordance with modern demands of society;

Table 1

SME Development Programs (Honcharenko, 2017)

\begin{tabular}{|l|l|}
\hline \multicolumn{1}{|c|}{ Initiator } & \multicolumn{1}{c|}{ Description } \\
\hline Canada & $\begin{array}{l}\text { Canada-Ukraine Trade and Investment Support (CUTIS) Project; Partnership for Local Economic Development and } \\
\text { Democratic Governance (PLEDDG) }\end{array}$ \\
\hline USA & Leadership in Economic Governance (LEG/LEV) \\
\hline USAID & $\begin{array}{l}\text { USAID Ukraine Trade Policy Project (UTPP) (USAID / International Development Group (IDG)); Action plan for } \\
\text { reforming the customs system (USAID / IBI International); Creating better business environment program (FORBIZ } \\
\text { project within EU4Business) (International Technical Assistance, EBRD, EIB) }\end{array}$ \\
\hline Switzerland & $\begin{array}{l}\text { Strengthening small and medium enterprises business membership organizations project (Switzerland's government } \\
\text { (SECO) - United Nations Development Programme (UNDP)) }\end{array}$ \\
\hline Sweden & $\begin{array}{l}\text { Promoting Ukrainian SMEs in the fruit and vegetable sector in the output on global and domestic markets and creating } \\
\text { added value (the Swedish Government / ITC) }\end{array}$ \\
\hline EU & SME Flagship Initiative within the framework of the Deep and Comprehensive Free Trade Areas \\
\hline
\end{tabular}


- low pace of implementation of new information and communication technologies in all spheres of social life, including open source software;

- lack of automated systems at the level of regional authorities, which prevents communication between regional authorities and society;

- lack of subdivisions ensuring the implementation of informatisation at the regional level (Prohramy informatyzatsii. "Elektronna Lvivshchyna”, 2017).

In order to increase the possibilities of informatisation of society, the government of the state actively uses political tools of the attraction of investment resources without paying attention to the rationality of distribution of public funds. According to recent research by UNCTAD on investment promotion, the main purpose of investment resources is the creation of new jobs, then technology transfer and export promotion, the main sectors in Ukraine are the information technology and business services sector, then agriculture and tourism. An important factor in the growth of investment revenues, through which it is possible to increase the national program of informatisation of society, is an increase of national investment security. For Ukraine, in order to successfully implement the national program of informatisation, a broad and narrow analysis of all directions and areas where consumers are ordinary citizens of Ukraine should be conducted (Motuzka, 2016).

Today, in order to carry out and ensure national competitiveness and increase investment attractiveness to carry out a wide informatisation of society, the following problems should be solved:

- high level of corruption;

-the emergence of collisions in the field of informatisation as a result of gaps in the legislative framework;

- insufficient state financing of domestic scientific institutions;

- imperfect methodological provision of investment project preparation;

- shortage of experienced and skilled specialists in project management;

- lack of practical experience and poorly developed infrastructure of venture capital investments, and so on (Dyskina, Krasnenska, 2017).

However, it should be noted that the process of informatisation of society has certain problem issues, which is manifested in the threat of using advances in the information sphere. In defining the speed of development of this area, unlike the legal organizational and technological sphere, information one is the least protected element of the state mechanism. Implementation of the national program of informatisation of society in the context of its financing the process of implementation of the program should be based only on the internal resources of the state, in order not to depend on external factors, as well as other states. The development of an information society supported by the state should have preconditions for sociocultural involvement when all goals are relevant to the possibilities of society. Financing of the national program of informatisation of society can be fully ensured in conditions of active cooperation between the state and society because most of the financial resources belong to the population of Ukraine.

\section{The vector of development of informatisation of society}

Positive and negative trends in the informatisation of society against the background of the active introduction of the state program of information society should be noted: - electronization of socio-economic and socio-political relations aimed at influencing the engineering and technical process, design, production, distribution of electronic technologies, which are integrated into production, used in scientific research, household appliances, transport, communication facilities, etc.; - computerization of society - as a process that takes place on the basis of the active growth of the role of information technologies in all spheres of society's life; - mediatization of society - a process determined in the creation and distribution of the latest systems of collective communication (Kyvliuk, 2011).

The proposed scheme (Figure 1) is a vector of information society development and has the key components that form a system that can be used in the development of long-term plans. The key components of the presented scheme are the following: directions for infrastructure development, negative factors, security tools, and positive effect.

Negative factors in the direction of the informatisation of society determine the main reasons why it is impossible to further develop a society in the context of infrastructure development for the formation of the information society. The directions of infrastructure development are possible elements, which should first of all be formed in the state strategy of informatisation and have a common vector of development and management. The security tools represent measures in the process of informatisation of society in various spheres of life of society and the state, namely:

- infrastructure development on the Internet;

- introduction of integrated information and telecommunication systems in different sectors of economies of the world countries;

- formation in all government bodies of the structural units responsible for information and computer resources support;

- ensuring the protection of information, both confidential and public at the level of the legislative field of countries;

- creation of expanded information on the use of various electronic services that will be implemented and available for each citizen of the state. 

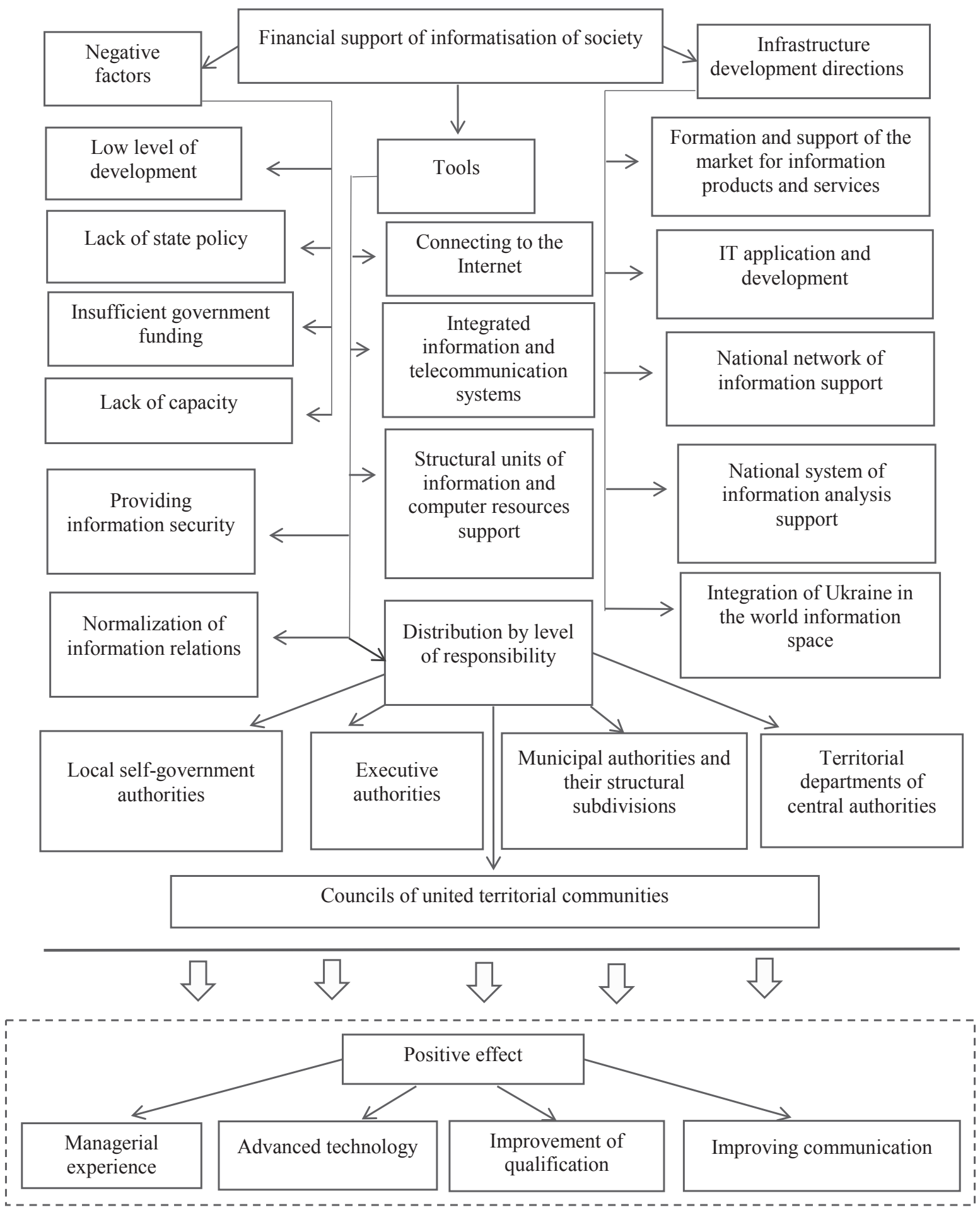

Figure 1. Development vector of informatisation of society

Source: the scheme is formed based on all sources used

One of the tools to ensure the fulfilment of the task of the informatisation of society is the division of powers in the hierarchy of state authorities, both at the level of central and local authorities. The final component is the positive effects of the implementation of all the measures, factors, and directions mentioned above.

\section{Conclusions}

Based on the foregoing, it should be noted that the information society is a prism of the functioning of democratic institutions and an important test for society itself in the context of the implementation of the state program of informatisation of society and its 
financing. Important prerequisites for financing the program of informatisation are the factors contributing to the expansion of the system of representative democracy and the active involvement of society.

Implementation of information technologies in society is important, namely, provides access to information and data protection for every person in the community, establishes communication between state authorities and society, reduces the costs of cooperation between different representatives of the third sector, private business, and state authorities. Thus, the state program of informatisation of society provides the opportunity to form public institutions as one of the important elements of statehood and attracting investments in order to develop and implement the realities of the demands of society in various spheres of life.

\section{References:}

Pro Natsionalnu prohramu informatyzatsii [About the National Program of Informatization] Zakon Ukrainy, 2016. Retrieved from: http://zakon5.rada.gov.ua/laws/show/74/98-\%D0\%B2\%D1\%80

Pro Kontseptsiiu Natsionalnoi prohramy informatyzatsii [About the Concept of the National Program of Informatization] Zakon Ukrainy, 2013. Retrieved from: http://zakon2.rada.gov.ua/laws/show/75/ 98-\%D0\%B2\%D1\%80

Kozak L.S. (2017). Inozemni investytsii v ekonomitsi Ukrainy [Foreign investments in the economy of Ukraine] Ekonomika ta upravlinnia na transporti, Vyp. 4, pp. 109-115.

Honcharenko O.V. (2017). Stymuliuvannia rozvytku it-sektoru: svitovyi dosvid ta ukrainski realii [Stimulating the IT sector development: world experience and Ukrainian realities]. Retrieved from: http://eztuir.ztu.edu.ua/ handle/123456789/7024.

Prohramy informatyzatsii. "Elektronna Lvivshchyna" (2017). [Informatization programs. "Electronic Lviv Region"]. Retrieved from: http://www.oblrada.lviv.ua/UserFiles/Image/docs/proekt/2017/proekt_840.PDF

Motuzka O.M. (2016). Perspektyvy rozvytku sfery priamoho mizhnarodnoho investuvannia [Perspectives for the development of direct international investment]. Retrieved from: http://194.44.12.92:8080/jspui/ bitstream/123456789/2392/1/\%D0\%9C\%D0\%BE\%D1\%82\%D1\%83\%D0\%B7\%D0\%BA\%D0\%B0.pdf

Dyskina A.A., Krasnenska O.B. (2017). Problemy zaluchennia inozemnykh investytsii v ekonomiku Ukrainy [Problems of attracting foreign investments into the economy of Ukraine]. Retrieved from: https://economics.opu.ua/files/ science/form_ek rozv/2017/30.pdf

Kyvliuk O.P. (2011). Informatyzatsiia ta informatsiina tsyvilizatsiia: sotsialno-filosofskyi aspekt [Informatization and informational civilization: socio-philosophical aspect]. Retrieved from: http://enpuir.npu.edu.ua/ bitstream/123456789/14418/1/Kyvluk.pdf

Hurkovskyi V.I. (2010). Zarubizhnyi dosvid formuvannia informatsiinoho suspilstva: perspektyvy adaptatsii $\mathrm{v}$ Ukraini [Foreign experience in the formation of information society: perspectives of adaptation in Ukraine] Publichne upravlinnia: teoriia ta praktyka, № 2, pp. 51-57.

Riabokon O. (2016). Derzhavna informatsiina polityka formuvannia informatsiinoho suspilstva: zarubizhnyi dosvid [State information policy for the formation of information society: foreign experience] Nauk. pr. Nats. b-ky Ukrainy im. V.I. Vernadskoho : zb. nauk. pr., Vyp. 43, pp. 97-114. 